\title{
PENGARUH KEPEMILIKAN MANAJERIAL DAN KEPEMILIKAN INSTITUSIONAL TERHADAP KEBIJAKAN HUTANG PERUSAHAAN DALAM PERSPEKTIF AGENCY THEORY
}

\author{
Elva Dian Pertiwi \\ Aftoni Sutanto \\ Universitas Ahmad Dahlan
}

\begin{abstract}
ABSTRAK
This study aimed to determine the effect of managerial ownership and institusional ownership as well as the control variabel is profitability, firm size, asset structure, against debt policy. The population in this is a property and real estate company listing on the Stock Exchange in 2010-2013. Purposive sampling with sampling to obtain a sample of 10 property and real estate using purposive sampling to obtain a sample of 10 companies and real estate properties companies. Data collection is done by the method of documentation. The analytical method used is multiple liniear regression analysis. With the influence that occurs between managerial ownershipand institusional ownership variable control of the debt policy on property and real estate companies on the Stock Exchange, the company should reduce the proportion of debt financing in order to reduce financial distress, because the funding of corporate debts causes financial distress and agency cost is greater than the tax savings from the burden of debt interest, consequently the company highly vulnerable to economic shock.
\end{abstract}

Keywords : managerial ownership, institutional ownership, profitability, company size, asset stucture, debt policy.

\section{PENDAHULUAN}

Tujuanutamaperusahaamemaksimumkan kemakmuran pemegang saham. Pemegang saham mempercayakan pada profesional yaitu manajer. Para manajer diberi kekuasaan oleh para pemilik perusahaan, yaitu pemegang saham, untuk membuat keputusan, dimana hal ini menciptakan potensi konflik kepentingan yang dikenal sebagai. teori keagenan (agency theory) (Brigham dan Houston, 2006) dikarenakan tujuan pemegang saham berbenturan dengan tujuan pribadi manajer.

Kondisi seperti ini akan mengakibatkan munculnya masalah keagenan, yang akan mengakibatkan agency cost yang harus dikelola dengan berbagai cara. Keberadaan agency cost jelas akan menyebabkan nilai perusahaan tidak bisa tercapai dengan secara maksimal. Sedangkan tujuan perusahaan meningkatkan nilai perusahaan melalui peningkatan kemakmuran pemilik atau pemegang saham (Brigham dan Gapenski, 1999). Biaya agency cost antara manajer dan pemegang saham dapat diminimumkan melalui berbagai pendekatan yang lebih efektif sehingga dapat mensejajarkan kepentingan-kepentingan yang terkait tersebut, di antaranya : Pendekatan pertama, dengan meningkatkan kepemilikan saham perusahaan oleh manajemen, Pendekatan yang kedua ialah melalui peningkatan Dividen Pay Out Ratio (DPR), Cara untuk mengurangi biaya keagenan yang ketiga, ialah menggunakan 
kebijakan hutang, peningkatan pendanaan dengan hutang bisa digunakan untuk mengurangi atau mengontrol konflik keagenan. Pendekatan keempat, dengan cara mengaktifkan monitoring melalui investor-investor institusional. Moh'd et al (1998) menyatakan bahwa distribusi pemegang saham antara pemegang saham dari luar yaitu institusional investor dan shareholders dispersion dapat mengurangi agency cost.

\section{REVIEW LITERATUR DAN HIPOTESIS}

\section{Landasan Teori}

Pearce dan Robinson (2008), mendefinisikan bahwa teori keagenan merupakan sekelompok gagasan mengenai pengendalian organisasi yang didasarkan pada keyakinan bahwa pemisahan kepemilikan dengan manajemen menimbulkan potensi bahwa keinginan pemilik diabaikan. Ketika pemilik ataupun manajer mendelegasikan otoritas pengambilan keputusan pada pihak lain, terdapat hubungan keagenan antara kedua pihak tersebut

Muftukhah (2013) menjelaskan kepemilikan manajerial merupakan proporsi pemegang saham dari pihak manajemen yaitu eksekutif dan direktur yang secara aktif ikut dalam pengambilan keputusan perusahaan. Menurut Jansen dan Meckling (1976) salah satu cara untuk mengatasí masalah dan mengurangi biaya keagenan dengan meningkatkan kepemilikan saham oleh pihak manajemen. Menurut Friend and Lang (1988) kepemilikan manajerial memiliki hubungan kausal terbalik atau subtitusi dengan hutang.

Muftukhah (2013) menjelaskan kepemilikan institusional merupakan saham yang dimiliki oleh perusahaan lain yang berada di dalam maupun di luar negri serta saham pemerintahan baik dari dalam maupun luar negri. Moh'd et al (1988) menyatakan kepemilikan investor institusional akan mendorong peningkatan pengawasan yang lebih optimal terhadap kinerja manajemen.
Menurut Jensen dan Meckling (1976) ada suatu cara untuk menengahi permasalahan agensi adalah dengan meningkatkan hutang. Dengan semakin meningkatnya hutang dalam suatu perusahaan otomatis mau tidak mau perusahaan itu akan menamperoleh kontrol yang ketat kreditor atau peminjam dana.

\section{Hipotesis}

$\mathrm{H}_{1}$ : Kepemilikan manajerial mempunyai pengaruh terhadap kebijakan hutang perusahaan.

$\mathrm{H}_{2}$ : Kepemilikan saham institusional mempunyai pengaruh terhadap kebijakan hutang perusahaan.

$\mathrm{H}_{3}$ : Kepemilikan manajerial, kepemilikan institusional, beserta variabel kontrol profitabilitas, ukuran perusahaan, dan struktur aktiva secara bersama- sama berpengaruh signifikan terhadap kebijakan hutang perusahaan.

\section{METODE PENELITIAN}

Dalam penelitian ini periode pengamatan yang digunakan yaitu mulai dari tahun 2010 sampai dengan 2013. Data yang digunakan dalam penelitian ini adalah data skunder yaitu data yang diperoleh tidak secara langsung diambil dari perusahaan. Biasanya data yang diperoleh/dikumpulkan dan disatukan oleh studistudi sebelumnya atau yang diterbitkan oleh berbagai instansi lain. Data tersebut bersumber dari laporan keuangan dan laporan tahunan yang telah dipublikasikan oleh BEI tahun 2010 sampai dengan 2013 dan IDX Fact Book tahun 2010 sampai dengan 2013, dimana data yang digunakan merupakan data time series yaitu data yang menggambarkan sesuatu dari waktu ke waktu atau periode secara historis, serta dari sumber internet dan studi pustaka yaitu dengan membaca dan mempelajari buku-buku serta jurnal pendukung lainnya. 
Data yang digunakan dalam penelitian ini adalah data keuangan mengenai kepemilikan manajerial, kepemilikan institusional, total hutang, laba operasi, jumlah lembar saham yang beredar, dan aktiva perusahaan. Dalam penelitian ini data yang paling banyak diambil adalah data mengenai profil perusahaan dan laporan keuangan perusahaan. Data- data yangdiperoleh dari hasil penjelajahan internet.

Populasi yang akan diteliti dalam penelitian ini adalah perusahaan properti dan real estate yang selama empat periode waktu yaitu 2010 sampai dengan 2013 di Bursa Efek Indonesia serta melaporkan laporan keuangannya secara lengkap dan dipublikasikan, sebanyak 37 perusahaan. Sample adalah bagian dari jumlah dan karakteristik yang dimiliki populasi tersebut (Sugiyono, 2008). Untuk menentukan sampel atau sejenis yang bisa mewakili populasi dalam jumlah tertentu. Sampel dalam penelitian ini diambil sebanyak 10 perusahaan. Berikut ke-10 perusahaan yang akan diteliti :

Tabel 1

Nama perusahaan properti dan real estate di BEI yang menjadi sampel

\begin{tabular}{|l|l|l|l|}
\hline$N_{0}$ & Nama Perusahaan & No & Nama Perusahaan \\
\hline 1 & PT. Agung Podomoro Land Tbk. & 6 & PT. Megapolitan Development Tbk. \\
\hline 2 & PT. Bukit Darmo Properti Tbk. & 7 & PT. Metropolitan Kentjana Tbk. \\
\hline 3 & PT. Ciputra Development Tbk. & 8 & PT. Pakawon Jati Tbk. \\
\hline 4 & PT. Duta Pertiwi Nusantana Tbk. & 9 & PT. Ristia Bintang Mahkotasejati Tbk. \\
\hline 5 & PT. Jakarta Intemasional Hotel \& Dev. Tbk & 10 & PT. Summanecon Agung Tbk. \\
\hline
\end{tabular}

Sumber: IDX Fact Book, (2015)

Dalam penelitian ini teknik pengambilan sampel menggunakan teknik purposive sampling, yaitu sampel dipilih berdasarkan pertimbangan atau kriteria sesuai dengan tujuan peneliti. Kriteria-kriteria tersebut antara lain: (1) Perusahaan properti dan real estate yang terdaftar di BEI dan melaporkan keuangan yang lengkap selama 4 tahun berturut-turut dari tahun 2010 sampai 2013,(2) Terdapat kepemilikan manajerial dan kepemilikan institusional atas saham yang beredar, (3) Memiliki informasi tentang rasio hutang perusahaan yang ditunjukkan oleh debt to asset ratio.

\section{Definisi Operasional dan Pengukuran Varia- bel}

Variabel Dependen dalam penelitian ini diproksikan dengan Debt to Asset Ratio (DAR). Menekankan pentingnya pendanaan hutang dengan jalan menunjukan persentase aktiva perusahaan yang didukung oleh hutang.

$$
\text { DAR }=\frac{\text { Total Kewajiban }}{\text { Total Aktiva }}
$$

Variabel Independen

a. Variabel Kepemilikan Manajerial merupakan ukuran prosentase saham yang dimiliki oleh pihak manajemen yang secara aktif ikut dalam pengambilan keputusan perusahaan (direktur dan komisaris). Variabel ini diberi simbol MOWN dan pengukurannya adalah sebagai berikut: MOWN $=\frac{\text { Jumlah kepemilikan saham yang dimiliki oleh manajerial }}{\text { Jumlah saham yang beredar }}$

\section{b. Variabel Kepemilikan Institusional merupakan prosentase saham yang dimiliki oleh investor institusional seperti perusahaan swasta, pemerintah (BUMN) dan LSM. Variabel kepemilikan institusional diberi simbol INST dan pengukurannya adalah sebagai berikut:}

INST $=\frac{\text { Jumlah kepemilikan saham yang dimiliki oleh institusional }}{\text { Jumlah saham yang beredar }}$

Variabel kontrol yang digunakan dalam penelitian ini didasarkan pada beberapa penelitian sebelumnya. Variabel kontrol berfungsi untuk melihat apakah dengan dimasukkannya variabel-variabel tersebut ke dalam model penelitian, pengaruh kepemilikan manajerial dan kepemilikan institusional terhadap kebijakan hutang menjadi semakin kuat sehingga dapat 
memperkecil error term. Variabel kontrol yang digunakan dalam penelitian ini antara lain:

1. Variabel profitabilitas perusahaan dalam penelitian ini diproksikan dengan Return on Asset (ROA) dan diukur dari rasio laba operasi terhadap total asset (Darsono dan Ashari, 2005).

$$
\mathrm{ROA}=\frac{\text { LabaBersih }}{\text { Total Aktiva }}
$$

2. Ukuran Perusahaan diukur berdasarkan total aktiva atau total asset yang dimiliki perusahaan. Variabel ini digunakan natural log total asset karena variabel lain berupa rasio, agar datanya normal data total asset dilogaritmakan (Dewanto, 2006). Variabel ukuran perusahaan ini diberi simbol SIZE. $S I Z E=$ Natural log total asset perusahaan

3. Struktur Aktiva Perusahaan diukur dengan menggunakan hasil bagi antara aktiva tetap terhadap aktiva total (Jensen, Solberg dan Zorn dalam Dewanto, 2006). Struktur aktiva diberi simbol FASSET.

$$
\text { FASSET }=\frac{\text { Aktiva tetap }}{\text { Total Aktiva }}
$$

\section{Metode Analisis}

\section{Analisis Regresi Berganda}

Penelitian ini menggunakan analisis regresi linier berganda untuk mengetahui besarnya pengaruh variabel-variabel bebas terhadap variabel terikat. Adapun persamaan regresi yạng akan digunakan dalam penelitian ini

$$
\begin{gathered}
\mathrm{DAR}=\mathrm{b}_{0}+\mathrm{b}_{1} \mathrm{MOWN}+\mathrm{b}_{2} \text { INST }+\mathrm{b}_{3} \mathrm{ROA}+\mathrm{b}_{4} \\
\text { SIZE }+\mathrm{b}_{5} \text { FASSET }+\mathrm{e}
\end{gathered}
$$

Dimana :

$\begin{array}{ll}\text { DAR } & =\text { Kebijakan hutang } \\ \text { MOWN } & =\text { Kepemilikan saham oleh } \\ \text { manajerial } & \\ \text { INST } & =\text { Kepemilikan saham oleh } \\ \text { institusional } & \end{array}$

ROA = Profitabilitas perusahaan

SIZE = Ukuran perusahaan

FASSET = Struktur aktiva perusahaan

$\mathrm{b}_{0} \quad=$ Konstanta Regresi

$\mathrm{b}_{1-5} \quad=$ Koefisien Regresi

$\mathrm{e}^{=} \quad$ Error term

Pengujian Hipotesis

Pengujian hipotesis dilakukan dengan uji signifikansi nilai $\mathrm{t}$ dan uji signifikansi nilai $\mathrm{F}$ untuk mengetahui besarnya pengaruh variabelvariabel independen terhadap variabel dependen baik secara parsial maupun secara serentak atau bersama-sama.

1. Uji signifikansi nilai $\mathrm{t}(\mathrm{t}$ test)

Pengujian ini dimaksudkan untuk mengetahui seberapa jauh taraf signifikan masing-masing variabel independen terhadap variabel dependen. Langkah-langkah dalam pengujian hipotesis sebagai berikut:

Merumuskan hipotesis, yaitu:

$\mathrm{H}_{1}$ : Variabel kepemilikan manajerial mempunyai pengaruh signifikan terhadap kebijakan hutang perusahaan.

$\mathrm{H}_{2}$ : Variabel kepemilikan institusional mempunyai pengaruh signifikan terhadap kebijakan hutang perusahaan.

Bila nilai $\mathrm{p}$ value $(\mathrm{sig})>\alpha(0,05)$ Ha ditolak

Bila nilai $\mathrm{p}$ value $(\mathrm{sig})<\alpha(0,05)$ Ha diterima

2. Uji signifikansi nilai $F$ (F test)

Pengujian ini dilakukan untuk mengetahui seberapa jauh seluruh variabel independen secara bersama-sama dapat mempengaruhi variabel dependen. Langkah-langkah dalam pengujian hipotesis adalah sebagai berikut:

Merumuskan hipotesis, yaitu:

$\mathrm{Ha}$ : Variabel kepemilikan manajerial, kepemilikan institusional, profitabilitas perusahaan, ukuran perusahaan, dan struktur aktiva secara simultanmempunyaipengaruh yang signifikan terhadap kebijakan hutang perusahaan. 
Bila nilai $\mathrm{p}$ value $(\mathrm{sig})>\alpha(0,05)$ Ha ditolak

Bila nilai $\mathrm{p}$ value $(\mathrm{sig})<\alpha(0,05)$ Ha diterima

Koefisien determinasi $\left(\mathrm{R}^{2}\right)$

Besar koefisien determinasi untuk mengukur prosentase pengaruh variabel kepemilikan manajerial, kepemilikan institusional, ukuran perusahaan, profitabilitas perusahaan dan struktur aktiva.

Semakin mendekati nol koefisien determinasi suatu persamaan regresi, maka semakin kecil pengaruh kepemilikan manajerial, kepemilikan institusional, ukuran perusahaan, profitabilitas perusahaan dan struktur aktiva terhadap kebijakan hutang. Semakin mendekati 1 besar koefisien determinasi suatu persamaan regresi, maka semakin besar pula pengaruh kepemilikan manajerial, kepemilikan institusional, ukuran perusahaan, profitabilitas perusahaan dan struktur aktiva terhadap kebijakan hutang.

\section{HASIL PENELITIAN DAN PEMBAHASAN}

\section{Uji Asumsi Klasik}

Uji Normalitas

Uji normalitas dilakukan untuk mengetahui apakah dalam sebuah model regresi, dependent variabel, independent variabel atau keduanya mempunyai distribusi normal ataukah tidak.

\section{Tabel 2}

Hasil Uji Normalitas (Kolmogorov-Smirnov)

\begin{tabular}{|l|l|}
\hline Asymp. Sig. (2-tailed) & 0.231 \\
\hline
\end{tabular}

Diperoleh nilai Asymp. Sig. (2-tailed) sebesar 0.231, dengan $\alpha=5 \%(0.05)$. Hal ini menunjukkan bahwa data yang digunakan memenuhi kriteria normal karena memiliki nilai Asymp. Sig. (2-tailed) $>0.05$.

Uji Multikolinieritas

Uji multikolinearitas dilakukan untuk menguji apakah dalam model regresi terdapat korelasi antara variabel independen. Deteksi adanya multikolinearitas jika nilai VIF lebih dari 10, maka persamaan model regresi tersebut mengandung multikolinearitas dengan variabel independen lainnya.

Tabel 3

Hasil Uji Multikolinieritas

\begin{tabular}{|c|c|c|}
\hline Variabel & Tolerance & VIF \\
\hline Kepemilikan Manajerial & 0.562 & 1.780 \\
\hline Kepemilikan Institusional & 0.790 & 1.266 \\
\hline Profitabilitas & 0.980 & 1.021 \\
\hline Ukuran Prusahaan & 0.623 & 1.604 \\
\hline Struktur Aktiva & 0.863 & 1.159 \\
\hline
\end{tabular}

Sumber: Data diolah, 2015

Dari hasil di atas dapat diketahui bahwa semua variabel bebas mempunyai toleransi yang sangat besar terhadap variabel bebas lainnya dimana nlai toleransi seluruhnya di atas 0,1 dengan nilai VIF (Variance Inflation Factors) kurang dari 10 , sehingga dapat disimpulkan bahwa variabel bebas yang digunakan dalam model penelitian ini tidak terjadi gejala multikolinieritas.

Uji Heteroskedastisitas

Uji heteroskedastisitas dilakukan untuk menguji apakah dalam model regresi terjadi ketidaksamaan varians dari residual satu pengamatan ke pengamatan lain. Jika hasilnya tetap maka disebut homokedastisitas.

\section{Gambar 1 Scatterplot}

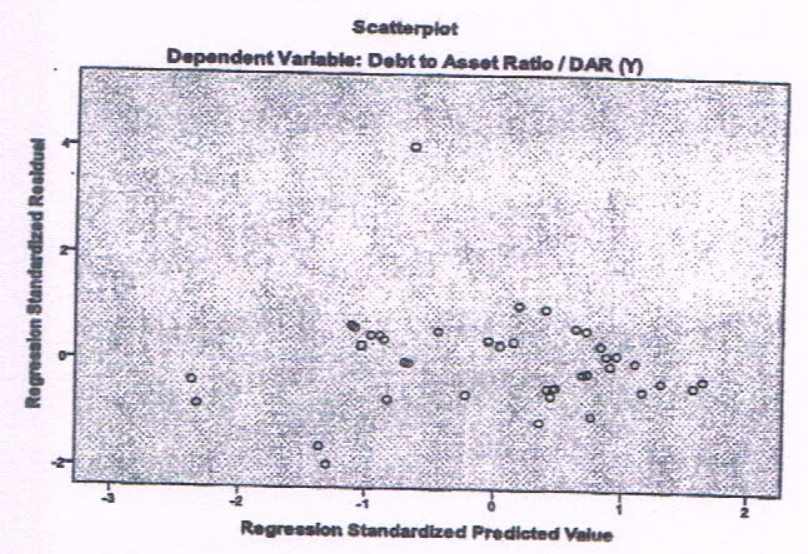

Sumber: Data diolah, 2015 
Jika ada pola tertentu seperti titik-titik yang ada membentuk suatu pola yang teratur (bergelombang, melebar, kemudian menyempit) maka telah terjadi heteroskedastisitas. Namun jika titik-titik tidak membentuk pola yang jelas, serta menyebar di atas dan di bawah angka 0 pada sumbu Y, maka heteroskedastisitas tidak terjadi.

\section{Uji Autokorelasi}

Pengujian ada tidaknya autokorelasi dilakukan dengan menggunakan metode Durbin Watson, yaitu dengan membandingkan nilai DW dari hasil regresi dengan nilai $d L$ dan $d U$ dari table DW.

Tabel 4

Hasil Uji Autokorelasi

\begin{tabular}{|l|c|}
\hline \multicolumn{1}{|c|}{ Keterangan } & Nilai \\
\hline$D l$ & 1,2305 \\
$d U$ & 1,7859 \\
$d \_$Value Regresi & 1,425 \\
$4-d U$ & 2,2141 \\
$4-D l$ & 2,7698 \\
\hline
\end{tabular}

Sumber: Data diolah, 2015

Dari tabel di atas terlihat bahwa $d$ value regresi terletak di antara $d L$ dan $d U$, sehingga berada pada keputusan tidak ada autokorelasi. Secara spesifik nilai D-W hitung terletak pada $d L<D W<d U$ maka dapat disimpulkan tidak terjadi autokorelasi pada model regresi.

\section{Analisis Regresi Berganda}

Hasil pengujian model regresi berganda terhadap faktor- faktor yang mempengaruhi Kebijakan hutang perusahaan dapat disajikan pada tabel berikut:

Tabel 5

Hasil Analisis Regresi Berganda

\begin{tabular}{|l|r|r|}
\hline \multicolumn{1}{|c|}{ Variabel } & $\begin{array}{c}\text { Koefisien } \\
\text { Regresi }\end{array}$ & \multicolumn{1}{c|}{ Sig. } \\
\hline Konstanta & -4.558 & 0.000 \\
\hline Kepemilikan Manajerial & 0.018 & 0.720 \\
\hline Kepemilikan Institusional & 0.649 & 0.007 \\
\hline
\end{tabular}

\begin{tabular}{|l|r|r|}
\hline Profitabilitas & 0.655 & 0.315 \\
\hline Ukuran Perusahaan & 0.275 & 0.000 \\
\hline Struktur Aktiva & -0.322 & 0.452 \\
\hline Sig. F & & 0.000 \\
\hline Adjusted R. Square & & 0.431 \\
\hline
\end{tabular}

Sumber: Data diolah, 2015

Berdasarkan hasil analisis, diperoleh persamaan regresi sebagai berikut:

$$
\begin{aligned}
\text { DAR }= & -4.558+0.018 \mathrm{MOWN}+0.649 \text { INST } \\
& +0.655 \text { PROF }+0.275 \text { SIZE }-0.322 \\
& \text { FASSET }+e
\end{aligned}
$$

Kepemilikan manajerial memiliki nilai signifikansi $(0,720)$ lebih besar dari taraf signifikansi $(\alpha) 5 \%$, dengan arah koefisien regresi yang positif terhadap hutang yaitu 0,018 . Dengan demikian hipotesis pertama ditolak, artinya kepemilikan manajerial mempunyai pengaruh positif dan tidak signifikan terhadap kebijakan hutang perusahaan.

Kepemilikan institusional memiliki nilai signifikansi $(0,007)$ lebih kecil dari taraf signifikansi $(\alpha) 5 \%$, dengan arah koefisien regresi yang positif terhadap hutang yaitu 0,649 . Dengan demikian hipotesis kedua diterima, artinya kepemilikan institusional mempunyai pengaruh positif dan signifikan terhadap kebijakan hutang perusahaan.

Profitabilitas perusahaan memiliki nilai signifikansi $(0,315)$ lebih besar dari taraf signifikansi $(\alpha) 5 \%$, dengan arah koefisien regresi positif terhadap kebijakan hutang perusahaan yaitu 0,655 .

Ukuran perusahaan memiliki nilai signifikansi $(0,000)$ lebih kecil dari taraf signifikansi (a) $5 \%$, dengan arah koefisien regresi positif terhadap kebijakan hutang perusahaan yaitu 0,275 .

Struktur Aktiva memiliki nilai signifikansi $(0,452)$ lebih besar dari taraf signifikansi $(\alpha) 5 \%$, dengan arah koefisien regresi negatif terhadap kebijakan hutang perusahaan yaitu $-0,322$. 
Uji simultan menunjukkan nilai signifikansi (0.000) lebih kecil dari taraf signifikansi $(\alpha) 5 \%$, sehingga hipotesis ketiga diterima.

Koefisien determinasi memiliki nilai 0,431 atau $43,1 \%$.

\section{Pembahasan}

1. Kepemilikan manajerial

Murtiningtyas (2012) menyatakan bahwa kepemilikan manajerial tidak berpengaruh terhadap kebijakan hutang, karena masih rendahnya kepemilikan saham oleh manajer dibandingkan dengan kelompok lainnya dalam perusahaan, sehingga manajer tidak dapat mengambil keputusan berdasarkan atas keinginannya sendiri. Manajer bukan merupakan faktor penentu dalam pengambilan kebijakan dari hutang. Sehingga dapat dikatakan bahwa kepemilikan manajerial tidak mempunyai pengaruh yang signifikan terhadap kebijakkan hutang.

Sehingga dapat disimpulkan karena prosentase kepemilikan saham manajer diperusahaan rendah menyebabkan manajer tidak bisa mengambil keputusan berdasarkan keinginannya sendiri dan sebagian besar keputusan bisa diambil oleh institusional karena merupakan pemegang saham tertinnggi di perusahaan sehingga memiliki kekuasaan tertinggi di perusahaan.

\section{Kepemilikan Institusional}

Murtiningtyas (2012) menyatakan semakin tinggi tingkat kepemilikan institusional maka kebijakan hutang akan ikut mengalami kenaikan. Bila dievaluasi, hasil penelitian ini dikarenakan kepemilikan institusional pada perusahaan properti dan real estate di Indonesia yang masuk dalam penelitian yang saya lakukan, pada umumnya sangatlah besar. Menurut Murtiningtyas, bahwa hutang yang meningkat menunjukkan pengawasan yang baik dari pihak pemegang saham sehingga meningkatkan minat kepemilikan institusional untuk memiliki saham perusahaan dan menyatakan bahwa perusahaan go publik di Indonesia dikendalikan melelui institusi atau badan hukum (PT). Mengenai hak pemegang saham dalam RUPS bahwa menghadiri dan memberikan suara dalam RUPS (Rapat Umum Pemegang Saham). Dalam hal ini satu saham yang dimiliki berarti satu suara dapat diberikan dalam RUPS. Karena kepemilikan institusional lebih besar dibandingkan dengan kepemilikan saham yang dimiliki oleh manajer maka suara terkuat jatuh pd kepemilikan institusional.

Penelitian ini memasukkan variabel profitabilitas, ukuran perusahaan dan struktur aktiva sebagai variabel kontrol. Dari hasil analisis menunjukkan bahwa profitabilitas berpengaruh positif dan tidak signifikan terhadap kebijakan hutang. Keadaan demikian mengindikasikan bahwa ketika tingkat profitabilitas perusahaan mengalami peningkatan dikarenakan perusahaan besar memerlukan dana yang besar untuk aktivitasnya sebagian besar keuntungan yang diperoleh perusahaan masih akan digunakan untuk pemenuhan sumber pembelanjaan (internal) investasinya, ketidaksignifikanan ini mungkin disebabkan bahwa hanya sebagian perusahaan yang tingkat profitabilitasnya meningkat, akan memanfaatkan kepercayaan para kreditur kepada perusahaan untuk menyalurkan kreditnya kepada perusahaan, dengan meningkatkan nilai utangnya sebagai sumber dana investasinya.

Ukuran perusahaan berpengaruh positif dan signifikan terhadap kebijakan hutang. Hal ini disebabkan perusahaan besar memiliki kebutuhan dana yang besar untuk membiayai aktivitasnya dan salah satu alternatif pemenuhan dana yang tersedia adalah dengan hutang. Keadaan demikian mengindikasikan bahwa ukuran perusahaan akan memberikan tingkat collateralized assetsyang dimilikinya akan semakin besar pula, sehingga akan mampu memberikan kepercayaan yang tinggi kepada para kreditur untuk menyalurkan kreditnya kepada perusahan. 
Struktur aktiva memiliki pengaruh negatif dan tidak signifikan terhadap kebijakan hutang perusahaan. Karena kepemilikan aktiva tetap yang besar dan adanya penawaran mengenai kemudahan pemberian pinjaman serta adanya kesempatan untuk berinvestasi akan menjadi pertimbangan bagi perusahaan untuk mengambil hutang. Dan struktur aktiva tidak mempunyai pengaruh yang signifikan terhadap sumber pendanaan dari hutang, karena apabila perusahaan mencari hutang sebagai sumber pendanaan utama akan semakin memperbesar biaya modal yang dikeluarkan.

Hasil pengujian secara simultan menunjukkan bahwa kepemilikan manajerial, kepemilikan institusional, profitabilitas, ukuran perusahaan dan struktur aktiva berpengaruh secara signifikan terhadap kebijakan hutang perusahaan.

Berdasarkan nilai koefisien determinasi, variabel kepemilikan manajerial, kepemilikan institusional, profitabilitas, ukuran perusahaan dan struktur aktiva hanya mampu menjelaskan variabel kebijakan hutang sebesar $43,1 \%$, sedangkan sisanya dijelaskan oleh variabel lain yang tidak diteliti.

\section{KESIMPULAN DAN SARAN}

Berdasarkan hasil analisis yang dilakukan maka dapat diambil kesimpulan bahwa hasil uji hipotesis secara parsial menunjukkan: (1) Kepemilikan manajerial mempunyai pengaruh positif dan tidak signifikan terhadap kebijakan hutang perusahaan, dan (2) Kepemilikan institusional mempunyai pengaruh positif dan berpengaruh signifikan terhadap kebijakan hutang perusahaan.

Hasil pengujian secara simultan menunjukkan bahwa kepemilikan manajerial, kepemilikan institusional, profitabilitas, ukuran perusahaan dan struktur aktiva berpengaruh secara signifikan terhadap kebijakan hutang perusahaan.
Saran untuk peneliti selanjutnya diharapkan sampel penelitian tidak hanya dari perusahaan properti dan real estate saja. Selain itu jangka waktu penelitian hendaknya lebih diperpanjang agar dapat menggambarkan kondisi sebenarnya dan menambah variabel-variabel penelitian yang diduga berpengaruh terhadap kebijakan hutang perusahaan, seperti free cash flow, dividen, risiko bisnis, pertumbuhan perusahaan dan lain-lain.

\section{DAFTAR PUSTAKA}

Brigham, F Eugene, Gapenski Louis, CDaves and Philip R. 1999. IntermediateFinancial Management. Sixth Edition. Orlando: The Dryen Press Dalamhttp:// dumadia.wordpress.com/2008/12/01/ analisissimultan// di unduh tanggal 1 Desember 2014).

Brigham, F. Eugene and Houston, F. Joel. 2006. Fundamentals of FinancialManagement (Dasar-Dasar Manajemen Keuangan). Edisi Kesepuluh Terjemahan Bahasa Indonesia, Buku 1. Jakarta: Salemba Empat.

Darsono, MBA. dan Ashari, SE., Akt. 2005. Laporan Keuangan. Yogyakarta: C.V Andi.

Dewanto, Chris Agus. 2006. Pengaruh kepemilikan Manajerial dan Kepemilikan Institusional terhadap Kebijakan Hutang Perusahaan dalamPerspektif Teori Keagenan. Skripsi. Yogyakarta: Universitas Muhammadiyah Yogyakarta.

Friend I and Lang, LHP. 1988. An Empirical Test of The Impact of Managerial Self Interest on Corporate Capital Structure. Journal of Finance. Vol. 43: Hal. 271282. 
Jensen dan Meckling, 1976. Theory of the Firm: Managerial Behafior, Agency Cost and Ownership Structure . Journal of Financial Economic. Vol 3. No.4.pp. 305-360.

Maftukhah, Ida, 2013. Kepemilikan Manajerial, Kepemilikan Institusional, dan Kinerja Keuangan sebagai Penentu Struktur Modal Perusahaan. Jurnal Dinamika Manajemen. JDM Vol 4. No 1. Pp. 6981 http://journal.unnes.ac.id/nju/index. php/idm (diunduh tanggal 1 Desember 2014).

Moh'd, M.A.,Perry, L.G \& Rimbey, J.N.1998, The Impact of Ownership structure on Corporate debt Policy: a Time -Series Cross -Sectional Analysis. Financial Review Social Science Research Network, Vol.33, Issue 3, pp: 85-98
Murtiningtyas, Andhika I. 2012. Kebijakan Deviden, Kepemilikan Manajerial, Kepemilikan Institusional, Profitabilitas, Resiko Bisnis, terhadap Kebijakan Hutang. Accounting Analysis Journal. AAJ Vol.1 No.2 . http://journal.unnes. ac.id/sju/index.php/aaj (di unduh tanggal 3 Desember 2014).

Pearce, John A dan Robinson Richard B. 2008 Manajemen Strategi, Formulasi. Implementasi, dan Pengendalian. Jakarta: Penerbit Salemba Empat.

Sugiyono. 2008. Metode Penelitian Bisnis. Bandung : CV. Alfabeta.

Tjeleni, Indra E. 2013. Kepemilikan Manajerial, Kepemilikan Institusional, Pengaruhnya Terhadap Kebijakan Hutang pada Perusahaan Manufaktur di BEI. Jurnal EMBA. Vol .1 No. 3. Hal 129-139. 